Горан Васин

Универзитет у Новом Саду

Филозофски факултет

Одсек за Историју

goranvasin@yahoo.com
Оригиналан научни рад

примљено: 1. јул 2012

прихваћено: 1. октобар 2012

\title{
ПАТРИЈАРХ ГЕОРГИЈЕ БРАНКОВИТ И ПРОТИВСРПСКЕ ДЕМОНСТРАЦИЈЕ У ЗАГРЕБУ 1895. ГОДИНЕ
}

Сажетак: Приликом посете цара Франца Јозефа Загребу октобра 1895 догодио се напад на српску цркву, заставу и неколико српских институција у Загребу. Нападнут је и сам патријарх Георгије али и више виђенијих Срба. Свештеници су доживели шиканирање, а доста Срба који су се нашли у цркви Преображења Господњег да поздраве владара, после посете били су изложени увердама и физичким нападима. Реакција српске политичке јавности била је жустра. Либерали и радикали су једнодушно осудили ове нападе, карактеришући их недостојним времена у коме се живи и недостојним Европе којом се хрватске политичке елите хвале представљајући себе носиоцима западне културе на Исток.

Кључне речи: Патријарх Георгије Бранковић, српска црква, застава, антисрпство, праваши, Анте Старчевић, радикали, Михаило Полит Десанчић, Краљевина Србија.

У време патријарха Георгија Бранковића на територији Краљевина Хрватске и Славоније налазиле су се две епархије, пакрачка и горњокарловачка, као и сама Архидијецеза. Духовна јурисдикција Карловачког патријарха није обухватала Далмацију. ${ }^{1}$ Још од времена када су почели да се насељавају у околину Загреба били су забележени њихови покушаји да организују своју црквену општину. По првом попису Загреба из 1819, било је 9136 становника, од чега је

\footnotetext{
* Текст је настао као фазни резултат рада на пројекту Војвођански простор у контексту европске историје (број 177002) Министарства просвете и науке Републике Србије.

${ }^{1}$ У време ових важних политичких дешавања пакрачки владика је био Мирон Николић, који је на трону епископа наследио Никанора Грујића. Владика Мирон Николић је на челу пакрачке епархије био до своје смрти фебруара 1941. године. Он је 1908 био изабран за патријарха, али његов избор није потврђен. После смрти Лукијана Богдановића октобра 1913. године, Администрирао је Митрополијом од марта 1914. године. Епископ горњокарловачки у време Бранковићевог избора био је Теофан Живковић, а њега на катедри горњокарловачких епископа 1891. године наслеђује Михаило Грујић. Управо је Грујић био први Адмнистратор Митрополије после Богдановићеве смрти, од октобра 1913. до марта 1914. када је умро у Плашком.
} 
православних 25. Православци су, међутим, још 1794. купили капелу на јавној лицитацији коју су посветили Св. Преображењу. Први председник црквене општине био је Јован Штова. Цркву су 1818. посетили цар Франц и царица Каролина, о чему је у Новинама сербским писао Димитрије Давидовић. Већ од 1861, како је број Срба у Загребу почео да расте, решено је да се почне зидати нова већа црква. Одбор је сазван 1864, а од 1866. члан је постао и Јован Суботић, док се знаменитих личности спомиње и Ђура Даничић. Благословом епископа пакрачког Никанора Грујића почело се са зидањем 1865. Црква је први пут освећена 1866, а унутрашњост храма, коју је радио чувени Херман Боле, је завршена и освећена од стране епископа пакрачког тек 1883-1884. ${ }^{2}$ Први на списку приложника са пет стотина форинти је био цар Франц Јозеф, а на другом месту са истом сумом митрополит Србије Михаило Јовановић. ${ }^{3}$

Да би на прави начин разумели догађаје из октобра 1895, потребно је нагласити значај и снагу коју су имали Срби у Загребу у том моменту. У периоду после 1881, када је Војна крајина присаједињена Цивилној Хрватској, број Срба у Хрватској је износио 26,3\%. Са том чињеницом треба истаћи да су по изборном законику имали 28 посланика у Сабору. ${ }^{4}$ Полако али сигурно, Загреб је преузео примат од Новог Сада у позицији на политичкој сцени Срба у Монархији. Срби у Хрватској су одступили од борбе против дуализма политиком која је позната као нотабилитетска, а била је ојачана у време бана Куена Хедерварија. ${ }^{5}$ Управо у тој чињеници је била клица коју су поједини хрватски политичари користили у распиривању мржње према Србима. Економско јачање Срба, било је трн у оку праваша, али и хрватске опозиције, која је сарадњу водећих личности српског покрета са баном (и напоменимо хрватским владајућим странкама) доживљавала као нарушавање интегритета и државно-правног положаја Хрватске. ${ }^{6}$ Оснивање

\footnotetext{
${ }^{2}$ Видети: Никанор Грујић, Автобиографија, Сремски Карловци 1907, 155.

${ }^{3}$ Дејан Медаковић, Срби у Загребу, Нови Сад 2004, 47-51.

${ }^{4}$ Што се тиче броја Срба у Хрватској, средином XIX века они су чинили око трећине становника Банске Хрватске и Хрватско-славонске војне крајине. По попису из 1840. у цивилном и војном делу Хрватске број Срба је износио 31, 41\% становништва, а тај број је 1857. пао на 29, 4 \%. На следећем попису цифра се кретала око 27, 84\%. (Василије Ђ. Крестић, Хрватско-угарска нагодба 1868, Београд, 1969, 13; Василије Ђ. Крестић, Историја Срба у Хрватској и Славонији 1848-1914, Београд 1995, 37-38.)

${ }^{5}$ Српски политичари из Срема су 1878. донели тзв. Черевићки програм, којим су одступили од борбе против дуализма. Конкретан резултат нотабилитетске политике било је донешење тзв Српског закона из 1887 и релативне корекције Школског закона из 1888 године. Нотабилитети су променом курса опозиционе милетићевске политике покушавали да сарадњом са баном и Владом, најпе на листи Народне странке, а потом и оснивањем Српског клуба, ојачају и побољшају положај српске црквено-школске аутономије. Неопоходност другачијег приступа решавању српског проблема у Хрватској донео је нотабилитетима и српским посланицима епитет Куенових Срба, односно присталица режима који је жестоко нападана од опозиције. Морамо додати да је у режиму учествовала и хрватска Народна странка, што се касније често занемаривало. (О нотабилитетима и њиховој политици у Хрватској, у првом реду односу Срба према режиму бана Куена Хедерварија видети: Василије Ђ. Крестић, Историја Срба у Хрватској и Славонији 1848-1914, 289-381; Василије Ђ Крестић, Нотабилитети и њихова политика у Хрватској и Угарској, Сентандрејски зборник, бр 1, Београд 1987, 87-112)

${ }^{6}$ Победа Народне странке на изборима 1887 године, нанела је осетне губитке хрватској опозицији и Центруму. Председник Неодвисне странке Фрањо Рачки се обратио барону Јовану Живковићу, ради
} 


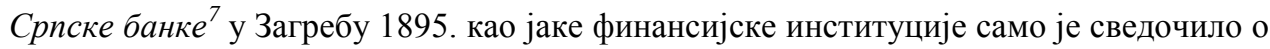
организованости и утицају Срба, што је још више правашку опозицију уверавало о томе како су Срби, уз помоћ угарске владе, велики кривци за лоше стање хрватског сељаштва и Хрвата уопште. Неразумевање и нетрпељивост према Србима први пут је јавно и масовно, са физичким нападима, исказана приликом посете цара Франца Јозефа Загребу у октобру 1895.

Самој посети цара била је поклоњена велика пажња у јавности. Загреб се спремао за овај важан политички догађај. Распоред је био познат неколико дана раније. Дана 14. Октобра 1895. у понедељак, Цар и угарски председник Владе барон Дезидер Деже Банфи су стигли са својом пратњом у јутарњим сатима у Загреб. Планирано је да их дочека хрватски бан Куен Хедервари. До најситнијих детаља је испланиран пролазак улицама, сусрет са посланицима, градоначелником, црквеним великодостојницима, представницима војске. У три дана, колико је трајала посета, било је предвиђено да цар посети и православну цркву Св. Преображења и црквену општину. Јављало се и да патријарх Георгије Бранковић, коме је ово била друга посета Загребу ${ }^{8}$, стиже у дан раније пре почетка званичне манифестације и да ће боравити у стану Богдана Медаковића. ${ }^{9}$

заједничке акције са Србима против режима Куена Хедерварија. Резултат преговора је био споразум потписан 19 марта 1888, који су потписали Рачки, Смичиклас, Мразовић, Амруш, Брлић, Војновић (готово сви водећи људи странке Обзораша, који нису штедели Србе у својим опозиционим наступима током дугог низа година-Г.В). Они су у уводном делу споразума предлагали помирење пошто је последице сукоба биле жалосне, наглашавајући да се патриотични Срби и Хрвати договоре, и да се реши њихово унутршање питање у које се нико не може мешати, као ни у државноправни положај Хрватске. Хрвати и Срби су проглашени као два народа једног племена, али су оба народна имена призната, а Срби из Хрватске су један политички народ. Призната је и равноправност ћирилице и црквено-школска аутономија, али под условом да остане под државним оквиром Хрватске владе. Либерали Михаила Полит Десанчића су изјавили да подржавају овај предлог, а слично је препоручио и Јован Ристић. Што се тиче радикала они су одоборили споразум да се обара Хедервари, али нису прихватали тезу да су Срби и Хрвати један народ. Српски оодговор је стигао почетком 1890 године, а саставио га је Јован Живковић. Потписало га је 19 политичара међу којима и Михаило Полит Десанчић, Јован Јовановић Змај, Богдан Медаковић, Илија Вучетић, Дане Прица, Никола Гавела, и други. Предлог Неодвисњака је прихваћен, али је затражено јединство Срба у погледу црквено-школске аутономије, како у Угарској, тако у Хрватској. Тада су Обзораши већ кренули у сарадњу са Странком права и Јосипом Франком тврдећи да Хрватској може бити Срба, али не и српске народности. (Василије Ђ Крестић, Историја Срба у Хрватској и Славонији, 330-332, 334; Василије Ђ Крестић, Грађа о Србима у Хрватској, књ 2, 118-120)

${ }^{7}$ Српска банка је основана, 3. априла 1895. у Загребу од стране неколико Срба адвоката, као и имућнијих Срба. Банка је требала да окупи српски капитал, које се могао употребити да ојача српску привреду. Утицај банке могао се уочити када су под њеним окриљем основани српско друштво Привредник 1897, као и Савез српских земљорадничкох задруга 1898. У првом Управном одбору Српске банке били су највиђенији Срби од којих се издвајају барон Јован Живковић, др Богдан Медаковић, Владимир Матијевић, Лазар Дунђерски и други. Банка је званично почела да ради 1. јула 1895. и брзо је стекла велики углед, који је везан и за статус српског грађанства, што је још више разгневило одређене хрватске опозиционе странке, предвођене правашима. (Никола Гаћеша, Српске новчане установе у другој половини ХІХ и почетком XX века у Хрватској и Славонији, Зборник о Србима у Хрватској, књ. 4, Београд 1999, 120-124; Василије Ђ. Крестић, Загреб-политичко средиште Срба у Аустро-Угарској, Зборник о Србима у Хрватској, бр. 1, Београд 1989, 94-97)

${ }^{8}$ Бранковић је у току 1890 . први пут у својству српског патријарха боравио у Загребу са циљем да присуствује седницама Земаљског Сабора. Дана 22. Новембра 1890. у пратњи Исидора Ћирића стигао је 
Приликом примања депутација, одмах после доласка у Загреб, Франц Јозеф је одговорио патријарху Георгију да се нада да ће и даље подупирати верно и привржено лично царево настојање да заштити српску цркву, као и да ће ширити хришћански морал, слогу и љубав. Већ тада се догодио напад на српску цркву и српске институције у Загребу. У знак поштовања према владару на српској цркви, Српској банци и Српској читаоници, постављене су српске заставе, али исто тако и царске и владине. Хрватски ђаци руковођени против Срба, најпре су напали паролом на српску заставу, прво су је гађали мастилом, каменицама и ножевима уз покличе: Доле. Не дуго затим су камењем разбили прозоре Српске куће и блокирали сав саобраћај у улици Илица, где се налазила српска црква и општина. Такво стање је трајало више од сат времена све док полиција није похапсила неколико ученика. Потом је на инсистирање полиције српска застава скинута са Српске куће и општине, тако да су поменути ђаци кренули и на српску цркву да и са ње скину заставу. Два прозора на цркви са скупоценим витражима су полупана. Неки од тих ђака су опколили патријархову кочију, а њих двадесетак су све време узвикивали и звижадали све док се Бранковић није одвезао. Дан раније у недељу патријарх је у цркви у Загребу одслужио свету литургију, а нагласио је да веру дедова треба стално бранити и да напади на веру долазе са разних страна готово свакодневно. ${ }^{10}$

Као израз велике милости цара према патријарху лично, владар је руку прво пружио Бранковићу, па затим грофу Елцу, надбискупу Посиловићу, Светозару Кушевићу и осталим присутним достојанственицима. У десет сати, само сат времена после доласка, цар је примио тајне саветнике међу којима је на првом месту био патријарх Георгије. Заједно са владикама пакрачким Мироном Николићем и горњокарловачким Михаилом Грујићем, у свом говору је рекао како жели да истакне своју приврженост владару, а и исто осећање преноси у име свештенства, монаштва и верног народа. Уобичајеним флоскулама пожелео је цару добро здравље и дугу владавину, тражећи за цркву, свештенство и народ владареву милост. Франц Јозеф је, како смо већ навели, узвратио патријарху да ће са милошћу бранити права српске цркве и народа.

Другог дана посете, цар се упутио у православну цркву Св. Преображења. На вратима цркве га је дочекао патријарх Георгије заједно са епископима Грујићем и Николићем. Током кратке службе отпевано је Многаја љета. Поново је у говору Бранковић рекао да је цар учинио велику част Србима и њиховој цркви својом посетом, уз жељу да владарски дом обрати пажњу на Србе и узме их у своју заштиту. Исто вече у згради Хрватског Сокола је организован бал, на коме је поред великодостојника Монархије био и патријарх са владикама. Поново је покренута тема напада на српске институције на улицама Загреба. Занимљиво је да док су

\footnotetext{
у Загреб где му је приређен дочек. У српској цркви одслужена је доксологија уз присуство свештенства горњокарловачке епархије. Бан Хедервари је дочекао Бранковића у банском двору где се уз многобројне здравице и пријатељску атмосферу и завршила прва посета српског патријарха Георгија Загребу (Георгије Магарашевић, Педесет година свештенства Његове светости патријарха Георгија Бранковића, Сремски Карловци 1905, 25-27)

${ }^{9}$ Србобран, бр 111/1895, 26. септембар/8. октобар

${ }^{10}$ Србобран бр. 114/ 2/14. октобар 1895.
} 
Срби упозоравали да се каменицама напада на њихову имовину, наводно то нико није то видео. Лично су полицајци тражили кључ од тавана Српске куће да би они сами скинули заставу. После тога, уследио је напад студената на српску цркву, да би поврх свега полицијски чиновници скинули српску заставу. Камењем су разбијани прозори на цркви. На лични налог бана Хедерварија заставе су враћене на цркву и општину. После посете делегације српској цркви, поново се скупљају студенти и већи број људи. Поново се камењем гађа црква и црквена општина. Разбијен је и прозор собе владике Михаила. Стање се релативно смирило тек на интервенцију жандармерије, али је потребно истаћи да су људи са оближњих тераса, укључујући и једног католичког жупника, такође бацали цигле на српске пролазнике. Ситуација се поново распламсала када је каменицама понов нападнута црквена кућа у улици Илица. ${ }^{11}$ Увреде су се чуле и на рачун Српске банке.

Око два сата, истог дана, у непријатној ситуацији се нашао српски патријарх. Можда је претерано рећи да је српски првојерарх једва избегао линч светине, али ако се зна да му је кочија била опкољена, да му се добацивало да крепа, да је гађан камењем, и да је било покушаја да се скине грб патријаршије са врата кочије, а да је све време био без заштите, ситуација није била безазлена. Помало епски приказано је како је кочијаш једва успео да избегне разуларену масу. Чак је поново интервенисла жандармерија, а било је и рањених. После тога камењем је гађана друга страна цркве, олтарска, а по извештајима полиције, ситуација је постајала критична. Од загребачког пароха Амвросија Павловића је затражено да откључа цркву и скине заставу. Биланс је био крајње забрињавајући. Полупани су сви прозори на цркви, шездесет стакала на црквеној кући, а мастило је просуто по Српској банци и цркви. ${ }^{12}$

Српско грађанство предвођено бароном Јованом Живковићем, обратило се истог дана 15 октобра, Георгију Бранковићу са захвалношћу што брани српску веру и цркву, али и са жаљењем што је морао да буде извргнут непријатностима у центру Загреба. Патријарх није пропустио прилику да спомене како је Србима потребна слога, али како слоге нема од времена како народ има тзв. аутономију (при томе је мислио на време од када су Милетићеви либерали преузели власт на Саборима у своје руке-Г.В). Лично је желео да се избори за боље дане свог народа доношењем Јединственог статута, али је сматрао да су за стање криви они који су били против доношења. ${ }^{13}$ Патријарх је после тога обећао да ће све учинити да се сазове нови Сабор који ће уредити стање ствари у српској аутономији.

Сви водећи бечки часописи пренели су вести о нередима у Загребу. Почетна тврдња да бискуп Штросмајер није у прилици да дође због слабог

\footnotetext{
${ }^{11}$ Србобран, бр 115/1895; Димитрије Витковић, Српска православна ирквена опћина, парохија и школа у Загребу, Загреб 1985, 68-70.

${ }^{12}$ Србобран, бр 115/1895

${ }^{13}$ На Црквено-народном сабору одржаном у Сремским Карловцима 1892 године поново се актуелизовало питање односа црквених великодостојника и лаика у управљању Црквом. Патријарх Бранковић и владике су покушале да редефинишу Устројство из 1875 године и омогуће превласт епископата, али је покушај осујетила саборска већина уз велике полемике и доста жучних расправа. (Горан Васин, Патријарх Георгије Бранковић и његово доба 1890-1907, рукопис, 24-32)
} 
здравља, ${ }^{14}$ још више је дала снаге његовим присталицама, као и симпатизерима Хрватске странке права Анте Старчевића. Нападане су српске и угарске заставе, а хрватски студенти отворено су демонстрирали против државе. У бечком листу Neue Freie Presse, истакнута је национална мржња против Срба и њихове заставе од стране хрватских демонстраната. На страницама познате аустријске новине писало се о посети цара Франца Јозефа и немилим догађајима који су се десили у Загребу. ${ }^{15}$ У првом плану била је чињеница да су Срби били за споразум са Угарском, а против Старчевићеве и Штросмајерове идеје о Великој Хрватској. Револт против Срба симболисао је и револт против владе, констатовано је у бечким новинама. Напади на свештенство српске цркве, били су у правом смислу речи погром. Митрополит дабробосански Николај Мандић називан је недостојним именима и вређан псовкама, свештеници су називани влашке с..., ${ }^{16}$ једном старом архимандриту из Босне исечена је мантија. ${ }^{17}$ Још неколико примера добро илуструје расположење према Србима тих дана у Загребу. Када је патријарх Георгије, после поменуте литургије у недељу, дан уочи доласка цара, беседио о српској цркви и православљу, каноници Вревц и Талијан, који су били присутни у цркви, прво су намигивали један другоме, да би на реч патријархову да се чува вера православна, Талијан стегнуо песницу и ударио по црквеном столу и чак узвикнуо: $x a .^{18}$

Београдске Српске новине, пренеле су вест да је сокачка руља правила демонстрације и напала српску имовину. ${ }^{19}$ Иначе је београдска политичка јавност помно пратила ове бурне догађаје, јављајући о великом узнемирењу које влада међу Србима у Хрватској. Напад на српску заставу који је учињен уз алузију да је у питању симбол туђе државе, посебно је анализиран у Београду. Праваши су направили читав атак на српску имовину и заставу, вређајући суседну државииу 20 Патолошки напади, фанатизована маса и малоумност организатора биле се прве реакције у Краљевини Србији. Пештер лојд је описивао стање после изласка цара из цркве, као ратно, и да је полиција једва успела да спречи веће инциденте и у самој цркви. Напоменута је и одлука бана Хедерварија да се застава одмах врати

\footnotetext{
${ }^{14}$ Штросмајер, иако је био слабог здравља, како се барем тврдило, живео је после ових догађаја још пуних десет година до 1905. (О делатности ђаковачког бискупа Штросмајера и његовом ставу о православцима ин Србима уопште, сведоче и следеће мисли које нису одступале сувише од погрда и увреда које су изговаране на улицама Загреба: видети: Василије Ђ. Крестић, Бискуп Штросмајер у светлу нових историјских извора, Нови Сад 2002; Василије Ђ Крестић, Бискуп Штросмајер, Хрват, Великохрват или Југословен, Јагодина 2009, 285-305)

${ }^{15}$ Neue Freie Presse, 16 october 1895, seite 2, nr 11187; Neue Freie Presse, 17 october 1895, seite 1-2, nr 11188 (у оба броја су анализирани недопустиви и скандалозни наступи вандала из Старчевићеве странке, која је представљена као државно правна опозиција, која криви између осталог Србе за сарадњу са Баном и Сабором на рачун Хрватске и Хрвата)

${ }^{16}$ У Србобрану се не наводи реч до краја али у Српском Сиону се јасно каже да су свештеници вређани са погрдом свиње влашке.

${ }^{17}$ Србобран, бр 115/1895.

${ }^{18}$ Србобран, бр. $116 / 1895$.

${ }^{19}$ Српске новине, бр 223, 2 октобар 1895

${ }^{20}$ Српске новине, бр 225, 6 октобар 1895
} 
назад на цркву. ${ }^{21}$ Пештанска штампа се посебно негативно изражавала о овим догађајима, захтевајући да бан Хедервари употреби силу против изгредника и да је раније пре посете морао да се постара да не дође до проблема. Мађарски водећи листови посебно су оштри били према случају узвикивања негативних парола против Угарске. ${ }^{22}$ Куен Хедервари је остао чврст у ставу после овог случаја да се дозволи употреба српске црквене заставе и грба Митрополије. На Угарском сабору, такође се говорило о овим догађајима. Ференц Кошут је анализирао стање у Хрватској, као нередовно, залажући се за испитивање целог случаја који је према његовим тврдњама осликаовао антидржавну опозицију Хрватске. Сличног мишљења је био и Алберт Апоњи. Генерално посланици Угарског сабора су тражили да се детаљно испита цео случај и захтева осуда понашања хрватске опозиције. Председник Владе барон Банфи је ипак случај релативизовао сматрајући да праваши нису довољно респектабилан политички фактор, али је осудио инциденте. ${ }^{23}$

Хрватска пак штампа трудила се да омаловажи патријарха Георгија тврдњом како му се цар није ни обратио, већ га је у потпуности игнорисао. Сион је са друге стране навео како се цар обратио патријарху поводом инцидената и рекао да су у питању гадне детињарије. Наводи се и пример надвојводе Леополда Салватореа, који није пропустио прилику да патријарху целива руку. ${ }^{24}$ Ради бољег сагледавања ситуације тих бурних дана у Загребу, морамо се осврнути на писање новосадске Заставе. Већ у првом помену догађаја везаних за напад на Србе, илустрација је да се у Загребу дешава велика комедија, коју су спровели великохрватски шовинисти. Срамотно је било то што су скидање српске заставе помогле и полицијске власти које су помагале фукару, како пише у колумни. ${ }^{25}$ Патријарх је стигао два дана раније и одсео у кући Медаковића, уз понављање свих изнесених чињеница које су биле идентичне са загребачком штампом, али уз посебан осврт на чињеницу да је надвојвода Леополд Салваторе, царев рођак, имао сусрет са патријархом при чему је чак два пута целивао његову руку што код католика није обичај. ${ }^{26}$ Као чињеница, узима се пример да ни Турци нису нападали на српске светиње, а да су православци чак у Цариграду били под бољом заштитом него у Загребу, где су наводно под заштитом бана Хедерварија. ${ }^{27}$

Ову прилику радикали су ипак далековидо искористили за изманеврисани напад на патријарха, који је желео да по њиховим сазнањима српску патријаршију премести из Карловаца у Будим. Тако се наводно већ увелико знало у Загребу како ће будимска епархија бити под директном јурисдикцијом српског патријарха, ко ће

\footnotetext{
${ }^{21}$ Српске новине, бр 225, 6 октобар 1895

${ }^{22}$ Српске новине, бр 226, 7 октобар 1895

${ }^{23}$ Српске новине, бр 231, 13 октобар 1895

${ }^{24}$ Србобран, бр 117/1895.

${ }^{25}$ Застава, бр. 154/ 4. октобар 1895.

${ }^{26}$ Застава, бр. 154/ 4. октобар 1895.

${ }^{27}$ Напад на Србе у Загребу, радикали су искористили као прилику да покажу колико је лоше то што нотабилитети подржавају Хедерварија, али и да је хрватски шовинизам чињеница која се мора имати у виду када су у питању односи Срба и Хрвата. (Застава, бр.159/ 13. октобар 1895.)
} 
бити и епископ будимски, а томе у прилог иде чињеница да је Георгије Бранковић 1893, почео да гради патријарашки двор у Будиму (?), што су потврдили владини кругови, а и пренео је Pester Lloyd. ${ }^{28}$ Помало романтичарски, али и контрадикторно у односу на ранији став, радикалски прваци су истакли да је патријарх тријумфално ушао у цркву, са одушевљеним узвицима народа, а са друге стране, споља су се чули узвици и повици којима су вређани Срби, као и њихов првојерарх. Заиста живописним речима у свом маниру Срби су приликом сусрета са царем, у својој цркви били испуњени задовољством, док су се Хрвати, као шкорпиони који су се грчили од муке и сами себе уједали (?). ${ }^{29}$

Радикали су у тексту Бан Хедервари и народ српски, упутили озбиљну критику бану који није заштитио Србе и њихову имовину, иако је законски био обавезан да то учини. Њима је посебно сметало што Срби имају илузија и подржавају Хедерварија, који суштински не чини ништа да обезбеди минимум егзистениције за Србе у Хрватској. Што се тиче напада на српску цркву он је окарактерисан као дивљаштво, и када човек помисли да су бесни Азијати Турии штедели српске иркве и манастире, када човек помисли да су недавно код иариградског покоља, једино у православним ирквама нађоше Јермени заштите за себе и свој угрожени живот, онда морамо дубоко уздахнути што су данас у деветнаестом веку, веку просвете- и Турии сто пута бољи и човечнији од хрватских Европљана. Српски народ, као да је знао да ће једном имати прилике да се огледа са грознијим Туриима од самих Турака, па је зато и рекао да ће друмови пожељети Турака али Турака више бити неће. ${ }^{30}$ Радикали су осули праву паљбу по Анти Старчевићу и хрватској интелигенцији која је окомила на Србе, тврдећи да је постало бљутаво и да човек не може да се не смеје када чује похвале о хрватској култури, како Хрвати носе западну културу на исток или како је Загреб јужнословенски Париз. Још једном је изречена опомена да Срби у Хрватској морају водити рачуна кога подржавају и са ким сарађују. Уредништво је подсетило и на речи патријарха Бранковића цару у коме је његов долазак у српску цркву окарактерисан као мелем на рану. ${ }^{31}$

Патријарх Георгије Бранковић и радикална странка су напоменимо још од маја 1890 били у жестоком сукобу и великом непријатељству. Између Бранковића и Заставе је беснео прави рат на дуги низ година. ${ }^{32}$ Можемо са сигурношћу тврдити

\footnotetext{
${ }^{28}$ У дугогодишњем сукобу између радикала и патријарха Бранковића, тврдња да Карловачки првојерарх чини све да средиште српске духовности премести у Будим била је једна од најчешћих оптужби. Суштински овај аргумент се користио као чисто вербално оружје за напад на епископат, који је према ставовима радикала био издајнички.

29 У извештају је речено да је улицама Загреба дивљала најобичнија руља. Видети: Лазар Ракић, Радикална странка у Војводини (до почетка ХХ века), 146; Застава бр. 155/ 6. октобра 1895; Застава бр. 156/1897; Застава, бр. 161/ 17. октобар 1895. (у наредним бројевима штампа је анализирала хртватске шовинистичке испаде и нарочито улогу Анте Старчевића у организовању и подстрекивању напада на Србе.)

${ }^{30}$ Застава, бр 155, 6 октобар 1895

31 Застава, бр 156, 8 октобар 1895 (текст Парче Африке у Троједници)

32 Од избора за патријарха априла 1890 године, радикали су нападали Бранковића као човека мађарске владе. Његови покушаји да измени устросјтво Црквено-народног сабора 1892 године, такозваним
} 
да су напади на Германа Анђелића, који су трајали у Застави од 1882 до 1888, били безазлени у односу на однос радикала према патријарху Георгију. Стога су противсрпске демонстрације у Загребу биле једна од ретких ситуација када се у Застави написало и нешто позитивно о Бранковићу. Очигледно да је лош утисак који је створен овим недопустивим нападима на српску цркву, био јачи од њихових свакодневних размирица.

Либерали Михаила Полит Десанчића огласили су се такође поводом свих ових напријатних дешавања. Браник је из дана у дан преносио вести и коментаре о нападима на српску цркву, заставу и непоштовање законом загарантованих оквира црквено-школске аутономије. ${ }^{33}$ Суштина српско-хрватских односа управо се огледала, према мишљењу либерала иначе великих присталица сарадње два народа, у оваквим манифестацијама које су суштински рушиле покушаје да се створи озбиљнији фронт према владиној политици. Они нису желели да се упуштају у дубље полемике са Обзором, који је бранио демонстранте, нападајући Србе за неслогу, већ су напросто аргументима подсећали да све српске покушаје и сарадње и одбрану хрватских интереса у периоду 1868-1873, 1881-1883 године, када је Полит Десанчић хваљен као велики пријатељ Хрвата. ${ }^{34}$ Либерали су анализирали и

Јединственим статутом њихове односе доводе на најнижу могућу тачку. Пуних 15 година до патријархове смрти радикали су водили кампању за његову смену, критикујући његову личност, руковођење црквом или стварањем различитих афера које су требале да дискредитију Бранковића, а које у највећој мери нису никада доказане. Када је патријарх умро јула 1907, у Застави је освануо некролог у коме је стајало да се прејео купуса са сланином и потом умро. (Видети: Горан Васин, Некролози о nатријарху Георгију Бранковићу, Истраживања бр 17, Нови Сад 2007, 229-239)

${ }_{33}$ Видети: Браник, бр 116, 5/17 октобар 1895; Браник, бр 117, 7/19 октобар 1895 (текст Како смо се провели у Загребу); Браник, бр 118, 10/22 октобар 1895; Браник, бр 119, $12 / 24$ октобар 1895; Браник, 120, 14/26 октобар 1895 (Кроз многобројне текстове, либерали су слали јасну политичку поруку да је сарадња Срба и Хрвата преко потребна, али да се мора поштовати српска национална посебност, која је приде призната законима. Либерале је посебно иритирало вређање православља, патријарха, ћирилице уз додатак да је предњачила студентска група. Став Обзора да се овим догађајима приступи неутрално или чак са оправдањем поступка хрватске омладине за либерале је био недопустив и поражавајућ. Тврдња да су Срби својим понашањем провоцирали и да су Срби кривци због чега нема слоге између два народа, Браник је карактерисао као грубу клевету).

${ }^{34}$ Исте 1895 земунски прота Димитрије Руварац написао је књигу Ево ита сте нам криви, коју је посветио нападима Обзора на Србе и српску политику. Он се критички осврнуо на чланак који је у Обзору бр 219 из 1894, са насловом Што смо криви? у коме се пита чему толика критика српскохрватских односа у светлу хрватске кривице за неразумевање и несарадњу. Руварац је ситематски корак по корак (седам разлога) доказивао да Хрвати и њихове леите раде на потирању и негирању свега што је српско и да то често чине и фалсификовањем историјских података. Навео је многобројне примере Армина Павића, Вјекослава Клаића, са фрапантним тврдњама о броју Срба и Хрвата у Босни и Херцеговини или чак фалсификовању српских народних песама. Посебно критички се осврнуо о деловању Фрање Рачког, бискупа Штросмајера, Анте Старчевића, Константина Војновића, Франка и католичких свештеника. Руварац је посебно биокиван на Штросмајера и Рачког и њихову прозелитску активност у Босни и Херцеговини и на просторима некадашње Војне границе. Он је доказивао читавим мноштвом примера од 1848 (и током Револуције) све до седница Сабора 1861 године кршење права Срба на равноправност или употребу ћирилице. Такође он је од Јелачићевог времена побројао велики борј случајева у којима се сарадња прекидала јер Хрвати нису желели да признају било какво уважавање српске заставе, ћирилице, или српске народности. Посебно је писао и о покушајима хрватских књижевника да српски језик прогласе хрватским. Руварац је анализом грба и заставе посебно упутио 
утицај римокатоличке цркве на стварање државне и политичке идеологије Хрвата и мржњи која је у дугом периоду стварана према протестантима и православцима. ${ }^{35}$ Њима је било несхватљиво да католички свештеници и данас (године 1895-Г.В) пропагирају унијаћење, верски фанатизам у моментима када се у целој Европи пропагира једнакост, братство, слобода вере. У складу са својим уверењима либерали су оваква начела називали средњовековним и заосталим.

На Хрватском сабору се водила полемика око ових догађаја на редовној седници 18/ 30 октобра 1895 године. Еразмо Барчић је говорио како поред српске заставе увек мора у срцима стајати и хрватска застава, док се за угарску одредио нешто другачије пошто према државним законима постоје сасвим одређена места и прилике за истицање мађарских државних обележја у Хрватској. Барчић је набрајао све покушаје које чини мађарска страна да понизи Хрватску и њену државност. ${ }^{36}$ Хедервари је подржао поштовање Срба и Хрвата, али није допуштао противдржавне иступе хрватске омладине. ${ }^{37}$ Ђура Ђурковић је инетрпелисао у смислу повреде

оштру примедбу на негацију српског постојања у Хрватској. Он је при том подсетио и на многобројне примере напада и изазивања мржње према Србима у дугом периоду апострофирајући Мажуранића, Рачког, Штросмајера и наравно Старчевића као кључне факторе ове антисрпске идеологије. (Димитрије Руварац, Ево шта сте нам криви, Земун 1895, 7-17, 24-37, 54-64, 73-90, 98-118, 131-140; Василије Ђ Крестић, Знаменити Срби о Хрватима, Нови Сад 1999, 129-141)

${ }^{35}$ Хрватски сабор је иначе током векова доносио читав низ закона који су директно били усмерени против протестаната и православаца. На Пожунској Дијети хрватски сталежи подносе тужбу да је у Хрватској католичка вера у опасности од „старовјераца“, и стога замоле Марију Терезију да укине сва шизматичка владичанства у Троједници, а да се управа и над унијатима и над шизматицима преда свидничком унијатском бискупу, да се одузме свака црквена власт у Хрватској и њеној Крајини православном митрополиту, а да се Привилегије уколико су од штете по католичку веру укину сасвим. Дијета је тада усвојила 46/1741, којим се оснажује 86/1723 по којем у Хрватској и Славонији неће бити друге вероисповести сем римокатоличке, а на територији ових земаља једино римокатолици могу имати непокретности. Српском православном митрополиту забрањује се јурисдикција у Карловачком и Вараждинском генералату. Царица је одредила да поред овога православни не могу у Хрватској и Славонији ни јавне службе вршити, обећавајући д аникакву власт неће допустити у Карловачком и Вараждинском генерлату карловачком митрополиту.) Када су 1751. на тадашњој Дијети Хрвати тражећи да поново буде оснажен 46/1741. добили о томе негативан одговор јер су Привилегије старије од законских чланака против православних, добили су га јер се 46/1741 позивао на 40/1635, 90/1659. и 46/1681. а они су могли важити само до доношења Привилегија, чијим су доношењем они обеснажени, што је само појачано потврдама истих од стране царева Јозефа I, Карла VI и саме Марије Терезије. Закони против протестаната су били из 1567. по којем нико ко није римокатолик не може имати непокретности у Хрватској и Славонији, што је потврђено 22/1604 (Јован Радонић, Римска курија и јужнословенске земље од XVI до ХІХ века, Београд 1950, 622-623; Манојло Грбић, Карловачко владичанство, Прва књига, Топуско 1990, 309-310; Јохан Хајнрих Швикер, Хисторија унијаћења Срба у Жумберку, Крагујевац 1991, 30; Манојло Грбић, Карловачко владичанство, Друга књига, Топуско 1990, 25-26; Zlatko Kudelić, Prvi marčanski grkokatolički biskup Simeon (1611.-1630.), Povijesni prilozi, 23, Zagreb 2002, 170-171)

${ }^{36}$ Српске новине, бр 239-240, 24-25 октобар 1895; Браник, бр 123, 21 октобра/ 2 новембра 1895 (либарали су нашли разумевања за Барчићев став да се осуди напад на Србе и мађарска хегемонија над Хрватском и њеним институцијама оконча)

${ }^{37}$ Полемика између праваша и бана Хедерварија је варничила у погледу државно-правног односа Хрватске и Угарске. Хрватска опозиција је нападала непоштовање хрватске државности од бана и његових послушника. 
српске црквено-школске аутономије, као кључног догађаја приликом демонстрација и сцена вандализма. ${ }^{38}$ Он је аргументовано тврдио да није била у питању провокација већ организована манифестација против српске цркве и школе. Ђурковић је једноставно желео да демистификује догађаје који нису били изгред изманипулисаних омладинаца или студената. Напросто у питању је било кршење закона који су санкционисани на Хрватском сабору.

Барон Јован Живковић, један од најзначајнијих српских политичара у Хрватској у другој половини 19 века, је за пешатанске листове, изрекао озбиљну осуду опозиционе политике. По Живковићу три фактора је учествовало у овим организованим демонстрацијама: руља, интелигенција и католичко свештенство. ${ }^{39}$ Обајшњење је према Живковићевим речима била неопосива мржња према свему што је српско, православно, и што подсећа на Србију. Он је разобличавао хајку коју опозиција води према српским институцијама, ћирилици, застави или српским истакнутим политичарима. Њега је посебно револтирао напад на српског патријарха, који је незамислив и у Турској или било где у цивилизованом свету, српске свештенике и вероисповест. Велико Хрватске тежње да се потире српска народност, и да се намеће теза да Срби у Хрватској постоје (већ да је реч о православним Хрватима-Г.В), само је део дугогодишње кампање која се води више од три деценије. ${ }^{40}$ Живковић је са разлогом констатовао да на територији Хрватске нема правих слобода и поштовања закона када су Срби у питању. ${ }^{41}$

Тако се током октобра и новембра 1895 у штампи и политичкој јавности коментарисао овај напад на српску цркву и институције у Загребу током посете цара

\footnotetext{
${ }^{38}$ Ђурковић је у дугачком говору анализирао Привилегије и законе како Угарског, тако и Хрватског сабора у којима је дозвољена употреба грба и заставе митрополије Карловачке. Он је посебно оштро одговорио на тврдње праваша да не постоји српска школа, српски грб и да је српска аутономија незаконита у Хрватској

39 Живковић је резонски истицао да студенти представљају будућу снагу и интелигенцију Хрватске, па се не може олако прећи преко податка да је велики број студената био међу онима који су рушили и палили. ${ }^{40}$ Да подсетимо у више наврата се између праваша и српских политичких представника водила полемика о негирању српског имена у Хрватској. На територији Троједне краљевине такође се писало о решавању националног питања на идеолошким основама које су често биле верске или чисто феудалне. Код Хрвата се нарочито осећао у том смислу идеолошки утицај Католичке цркве. Од времена бискупа Максимилијана Врховца, затим Илирског покрета 1830. и идеологије либералног католицизма долази до идеја које су у етничком погледу хрватским елитама давале аспирације према територијама које су морале припасти Хрватској: некадашње жупе од Пливе до Врбаса, Далмација, Истра до реке Раше, Пула, Славонија, Срем, Међумурје, део Крањске и Штајерске. Што се тиче примене Етвешове концепције у Хрватској, њу је дефинисао (применио) Анте Старчевић у делу Име Срб године 1868. Старчевић је тврдио да је у средњем веку једна петина становништва била господивша пасмина (владајући народ хрватски), а да је четири петине било зароба - Срба, чиме је означио и националну и социјалну категорију. Вођа Хрватске странке права је тако прихватио идеје Гобиноа и Етвеша који су о Србима писали као о нижој раси, и чије име је долазило директно од латинског назива роб (Гобино). На основу тих аргумената Старчевић је креирао теорију о готском пореклу Хрвата (Бранко Бешлин, Европски утицаји па српски либерализам у 19 веку, Нови Сад 2005, 430; Милорад Екмечић, Огледи из историје, Београд 1999, 303-315; Милорад Екмечић, О иркви и нацији код Хрвата, у: Зборник о Србима у Хрватској, бр. 4, Београд 1999, 7-35; Džordž Mos, Istorija rasizma u Evropi, Beograd 2005, 85-88, 103, 151-154).

${ }^{41}$ Српске новине, бр 242, 28 октобар 1895; Браник, бр 125, 26 октобар / 7 новембар 1895
} 
Франца Јозефа. Несумњиво је да су правашки кругови и део омладине орагнизовано извршили низ инцидената који су имали последице по политичке односе српских и хрватских елита. Преоговори који су вођени од 1888 године, нису уродили плодом, а међусобно неповерење у опозиционим српско-хрватским редовима је остајало. Ипак настојања да се превазиђе спор и неспоразум настављена су све до склапања хравтско-српске коалиције 1905. Исто тако у сложеним односима српске и хрватске политике у Хрватској понављале су се и противсрпске демонстрације наредних година. ${ }^{42}$ И поред многобројних покушаја сарадње који су још од 1861 ишли путевима борбе за равноправност језика и признавања црквено-школске аутономије, српска политика у Хрватској често је лутала између захетва за признавање хрватског државног права и очувања сопствене самосвојности. На Хрватском сабору не ретко су се чули говори да се једино мора чувати и признавати целовитост и самосвојност Троједне. Српски захтеви често су били скрајнути или су сматрани неоправданим. После периода управе бана Мажуранића 1874-1880, не може нас чудити што долази до промене курса српске политике, која је и даље тражила признавање језика, верске равноправности и обележја. Пошто Милетићево подржавање хрватске опозиције 1868-1873, није донело резултат, покушавало се другим путем. Доношење тзв Српског закона био је какав-такав успех, али је део хрватске политичке јавности сматрао да су генерално Срби нелојалан чинилац хрватске државе. Једна од првих манифестација овакве идеологије била је исказана октобра 1895 године у Загребу. Исходишта такве политике показаће лица и наличја свог деловања у врло кратком року.

\footnotetext{
42 Овакве сцене противсрпских испада у Загребу поновиле су се још неколико пута. Године 1899. приликом прославе педесет година рада песника Јована Јовановића Змаја, док су највеће по обиму и размерама биле 1902. Исте 1902. у априлу Краљевска земаљска влада, послала је епархијама горњокарловачкој и пакрачкој допис о новом начину вођења матрикула. Српска православна црква у будуће се мора називати грчко-источна без додатака. Обе епархије одмах су се обратиле Синоду (чија је седница одржана у јулу 1902. под патријарховим преседништвом) уз напомену да саме владике нису желеле без одлуке Синода да доносе било какве одлуке. Црква је била затечена и врло непријатно изненађена оваквим развојем догађаја. Сматрало се да таквим актом од Срба тражи да се одрекну вере и имена. Српским законом од 14. маја 1887. ово питање је јасно решено, па се Синод чудио оваквој одлуци владе. Наглашено је да се у црквеним стварима не може избацити назив- православна, српска, источноправославна. Напомена у вези са законом је да се по њему Срби називају грчко-источни, али да не пише да они морају себе тако да зову. Овакво стање ствари остало је неиздефинисано још дуг низ година. Сва акта која су коришћена у унутрашњим црквеним пословима и даље су вођена на стари начин, док је преписка са Земаљском владом текла по новим правилима и прописима. Објективно српска црква није имала шансе да утиче на доношење одлука Владе, већ углавном да се са мање или више протеста повинује. У току 1904-1905. патријарх је покушао да неуређено стање у црквама и школама у Хрватској поправи. Владика Михаило је у његово име говорио на седницама Хрватског сабора, али је његова интерпелација остала без већег успеха. (Василије Ђ. Крестић, Историја Срба у Хрватској и Славонији 1848-1914, 351-355; АСАНУК, МПА, А, 195/1902; Георгије Магарашевић, Педесет година свештенства, 91-93)
} 
Извори и литература:

Извори:

АСАНУК, МПА, А, октобар 1895, јул 1902 године.

Застава, Браник, Србобран, Српске новине и Neие Freie Presse.

Литература:

Бешлин, Бранко, Европски утищаји на српски либерализам у 19 веку, Нови Сад 2005.

Васин, Горан, Патријарх Георгије Бранковић и његово доба 1890-1907, рукопис необјављеног магистарског рада, Нови Сад 2008.

Васин, Горан, Некролози о патријарху Георгију Бранковићу, Истраживања бр 17, Нови Сад 2007.

Витковић, Димитрије, Српска православна ирквена опћина, парохија и школа у Загребу, Загреб 1985.

Гаћеша, Никола Српске новчане установе у другој половини ХIX и почетком XX века $y$ Хрватској и Славонији, Зборник о Србима у Хрватској, књ. 4, Београд 1999.

Грбић, Манојло, Карловачко владичанство, Прва књига, Топуско 1990.

Грбић, Манојло, Карловачко владичанство, Друга књига, Топуско 1990.

Грујић, Никанор, Автобиографија, Сремски Карловци 1907.

Екмечић, Милорад, Огледи из историје, Београд 1999.

Екмечић, Милорад, О иркви и наиији код Хрвата, у: Зборник о Србима у Хрватској, бр. 4, Београд 1999.

Крестић, Василије Ђ, Хрватско-угарска нагодба 1868, Београд, 1969.

Крестић, Василије Ђ, Историја Срба у Хрватској и Славонији 1848-1914, Београд 1995.

Крестић, Василије Ђ, Нотабилитети и ғихова политика у Хрватској и Угарској, Сентандрејски зборник, бр 1, Београд 1987.

Крестић, Василије Ђ, Загреб-политичко средиште Срба у Аустро-Угарској, Зборник о Србима у Хрватској, бр. 1, Београд 1989.

Крестић, Василије Ђ, Бискуп Штросмајер у светлу нових историјских извора, Нови Сад 2002.

Крестић, Василије Ђ, Бискуп Штросмајер, Хрват, Великохрват или Југословен, Јагодина 2009.

Крестић, Василије Ђ, Знаменити Срби о Хрватима, Нови Сад 1999.

Kudelić, Zlatko, Prvi marčanski grkokatolički biskup Simeon (1611.-1630.), Povijesni prilozi, 23, Zagreb 2002.

Магарашевић, Георгије, Педесет година свештенства Његове светости патријарха Георгија Бранковића, Сремски Карловци 1905.

Медаковић, Дејан, Срби у Загребу, Нови Сад 2004.

Микавица, Дејан, Политичка идеологија Светозара Милетића, Нови Сад 2006.

Mos, Džordž, Istorija rasizma u Evropi, Beograd 2005.

Радонић, Јован, Римска курија и јужнословенске земље од XVI до ХIX века, Београд 1950.

Ракић, Лазар, Радикална странка у Војводини (до почетка ХХ века), Нови Сад 1975.

Руварац, Димитрије, Ево шта сте нам криви, Земун 1895.

Швикер, Јохан Хајнрих, Хисторија унијаћеља Срба у Жумберку, Крагујевац 1991. 


\title{
THE PATRIARCH GEORGIJE BRANKOVIĆ AND ANTI-SERBIAN DEMONSTRATIONS IN ZAGREB IN 1895
}

\begin{abstract}
Summary
During the visit of the Emperor Franz Josef to Zagreb in October 1895, there was an attack on the Serbian church, the flag, and several Serbian institutions in Zagreb. The Patriarch Georgije was also attacked, as well as a few prominent Serbs. Priests were harassed, and a lot of Serbs who were in the church of the Transfiguration of the Lord to greet the monarch, were subjected to insults and physical attacks after the visit. Reaction of the Serbian political scene was brisk. Liberals and radicals unanimously condemned the attacks, characterizing them as unworthy of the times in which they lived, and unworthy of Europe which Croatian political elite was praising of, presenting themselves as carriers of the Western culture to the East. For some time, especially the Serbian press wrote and analyzed these events in the light of the Serbo-Croatian conflict.
\end{abstract}

Keywords: Patriarch Georgije Branković, the Serbian church, flag, anti-Serbian attitude, HSP, Ante Starčevi, radicals, Mihailo Polit Desančić, Kingdom of Serbia. 